PROCEEDINGS OF THE UNITED STATES NATIONAL MUSEUM

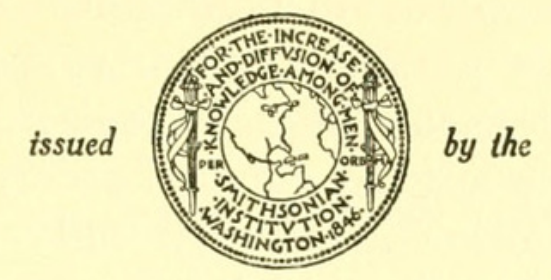

SMITHSONIAN INSTITUTION

U. S. NATIONAL MUSEUM

\title{
NEW SPECIES OF BUPRESTID BEETLES OF THE GENUS AGRILUS FROM TRINIDAD
}

\author{
By W. S. Fisher
}

A small collection of Agritus beetles, reported as being the prey of a crabronid wasp in Trinidad, British West Indies, was received from E. McC. Callan for identification. These specimens have been compared with the descriptions of all the species described from the Guianas, Venezuela, Colombia, Panama, the Canal Zone, and Costa Rica, and since no species of Agrilus have been described from Trinidad, and none of the specimens received seem to be any of the species described from the localities listed above, they are here described as new.

\section{Genus AGRILUS Curtis}

AGRILUS CALLANI, new species

Male.-Elongate, slender, subcylindrical, moderately shining; head in front green, bronzy brown on occiput; pronotum dark green on disk, with a distinct purplish tinge, and narrowly bronzy along lateral margins; scutellum bronzy brown; elytra black, with a faint purplish tinge and ornamented with white pubescent spots; body beneath black, with a feeble bronzy tinge, and femora slightly greenish.

Head with front broad, wider at top than at bottom, without distinct median depression; sides parallel posteriorly, strongly converging anteriorly; surface nearly glabrous, coarsely, shallowly, confluently punctate, and densely granulose on front and vertex, longitudinally costate on occiput; clypeus narrow between antennae, deeply, arcuately emarginate in front; antenna short, extending to apical third of pronotum, serrate from fourth segment. 
Pronotum quadrate, subequal in width at base and apex, widest along apical half; sides nearly parallel anteriorly, slightly converging posteriorly; posterior angles acute, slightly projecting outward; marginal and submarginal carinae slightly sinuate, widely separated anteriorly, united near base; anterior margin strongly sinuate, median lobe strongly produced and broadly rounded; base arcuately emarginate on each side, median lobe slightly produced, broadly subtruncate in front of scutellum; disk broadly, shallowly, transversely depressed along base, broadly depressed along lateral margins, vaguely, transversely flattened at middle near anterior margin, but without longitudinal, median depressions; prehumeral carinae strongly elevated, arcuate, united to marginal carinae at middle; surface nearly glabrous, coarsely, deeply, transversely rugose on disk, indistinctly punctate between rugae. Scutellum strongly, transversely carinate.

Elytra broadly, shallowly constricted in front of middle; tips separately broadly rounded, coarsely dentate, median tooth on each slightly longer than other teeth; surface vaguely depressed along sutural margins, densely, finely imbricate-punctate, each elytron ornamented with three small, white, pubescent spots, one in basal depression, one in front of middle, and one behind middle, and with a few white hairs along sutural margin near apex.

Abdomen narrowly exposed above, strongly convex beneath; surface densely, finely granulose, indistinctly punctate, nearly glabrous on median part, with sparse white pubescent spots at sides of first, third, fourth, and fifth sternites and on vertical portion of second sternite; suture obsolete between first and second sternites, the first sternite flattened at middle. Prosternum densely granulose, sparsely clothed with short, semierect, inconspicuous, white hairs; prosternal lobe long, broadly rounded in front; prosternal process broad, parallel at sides, truncate, with an obtuse median tooth at apex. Tarsal claws similar on all feet, cleft near middle, inner tooth of each slightly shorter than outer one, turned inward, but not touching tooth on opposite side.

Female.-Differs from the male in having the front of the head coppery and more feebly converging anteriorly, and the first abdominal sternite convex at the middle.

Length $6 \mathrm{~mm}$., width $1.4 \mathrm{~mm}$.

Type locality.-Talparo, Trinidad, British West Indies.

Type and allotype.-U.S.N.M. No. 56602. Paratype returned to Mr. Callan.

Remarks.-Described from three specimens (one male type), all collected at the type locality, December 25, 1941, by E. McC. Callan.

This species is allied to Agrilus fallax Say but differs from that species in being slenderer and more strongly acuminate posteriorly, in 
having the front of the head narrower with the sides strongly converging anteriorly, the clypeus narrow between the antennae, and the prosternal process not expanded behind the coxal cavities.

\section{AGRILUS PRAEDAE, new species}

Female.-Elongate, slender, subcylindrical, strongly shining, glabrous on dorsal surface, uniformly bIack, with a faint purplish reflection, except pronotum, which is reddish coppery.

Head with front broad, wider at top than at bottom, with a vague, broad, median depression; sides slightly sinuate, feebly converging from top to bottom; surface densely granulose, coarsely, vaguely punctate; clypeus rather narrow between antennae, shallowly, arcuately emarginate in front; antenna short, extending slightly beyond apex of pronotum, separate from fourth segment.

Pronotum slightly wider than long, subequal in width at base and apex, widest near apex; sides vaguely arcuate anteriorly, slightly, obliquely converging posteriorly; posterior angles rectangular; marginal carina straight, submarginal carina short, the two carinae parallel and widely separated anteriorly, united at middle; anterior margin strongly sinuate, median lobe strongly produced and broadly rounded; base arcuately emarginate on each side, median lobe slightly produced, subtruncate or vaguely emarginate in front of scutellum; disk broadly, shallowly, transversely depressed along base, more deeply, broadly depressed at middle along lateral margins, vaguely, transversely flattened at middle behind anterior margin, but without longitudinal, median depressions or prehumeral carinae; surface densely, finely granulose, finely, transversely rugose on disk, indistinctly punctate between rugae. Scutellum strongly, transversely carinate.

Elytra broadly, shallowly constricted in front of middle; tips separately broadly rounded and finely dentate; surface slightly flattened, densely, finely granulose, coarsely, densely imbricate-punctate.

Abdomen broadly exposed above, strongly convex beneath; surface densely, finely granulose, indistinctly punctate, sparsely, uniformly clothed with very short, recumbent, inconspicuous hairs; suture between first and second sternites vaguely indicated near middle. Prosternum densely granulose, coarsely, shallowly punctate, sparsely clothed with very short, erect, inconspicuous hairs; prosternal lobe long, broadly rounded in front; prosternal process broad, sides obliquely converging to apex, which is broadly rounded, with an acute, median tooth. Tarsal claws similar on all feet, cleft near middle, inner tooth slightly shorter than outer one, turned inward, touching tooth on opposite side.

Male.-Unknown.

Length 5.6-6 mm., width $1.4 \mathrm{~mm}$. 


\section{Type locality.-Talparo, Trinidad, British West Indies.}

Type.-U.S.N.M. No. 56603. Paratype returned to Mr. Callan.

Remarks.-Described from two females (one type) collected at the type locality, December 25, 1941, by E. McC. Callan.

This species resembles Agrilus infidelis Fisher but differs from that species in having the antenna serrate from the fourth segment and in not having prehumeral carinae on the pronotum or pubescent spots on the elytra.

\section{AGRILUS PICINUS, new species}

Male-Elongate, slender, subcylindrical, strongly shining, glabrous on dorsal surface; uniformly brownish black, with a slight greenish tinge on underside of body, and the head green in front, becoming brownish on occiput.

Head with front broad, wider at top than at bottom, with a vague, longitudinal, median depression on vertex; sides feebly converging from top to bottom; surface densely, finely granulose, sparsely, finely punctate, clothed with a few short, white hairs near clypeus; clypeus narrow between antennae, deeply, arcuately emarginate in front; antenna short, extending slightly beyond apex of pronotum, serrate from fourth segment.

Pronotum slightly wider than long, subequal in width at base and apex, widest near apex; sides nearly parallel anteriorly, obliquely converging posteriorly; posterior angles rectangular; marginal and submarginal carinae sinuate, widely separated anteriorly, united behind middle, the submarginal carina obsolete near apex ; anterior margin strongly sinuate, median lobe strongly produced and broadly rounded; base angularly emarginate on each side, median lobe broadly subtruncate in front of scutellum; disk broadly, transversely flattened along base, deeply depressed at middle along lateral margins, vaguely flattened at middle in front of middle, but without distinct longitudinal, median depressions and prehumeral carinae; surface finely, shallowly, transversely rugose on disk, finely granulose and indistinctly punctate between rugae. Scutellum strongly, transversely carinate.

Elytra broadly, shallowly constricted in front of middle; tips separately broadly rounded and very finely dentate; surface flattened on basal half, longitudinally depressed along sutural margins on apical half, densely, finely granulose, densely, coarsely imbricate-punctate.

Abdomen broadly exposed above, strongly convex beneath; surface indistinctly granulose, with fine, transverse, crenulate lines, which are more distinct on basal sternites, very sparsely clothed with short, recumbent, white hairs; suture between first and second sternites obsolete. Prosternum densely, coarsely scabrous, densely clothed with short, erect, white hairs; prosternal lobe long, subtruncate or vaguely, broadly emarginate in front; prosternal process broad, sides nearly parallel, 
obliquely converging at apex to an acute median tooth. Tarsal claws similar on all feet, cleft near middle, inner tooth of each slightly shorter than outer one, turned inward touching the tooth of opposite side.

Female.-Differs from the male in having the front of the head black and the pubescence on the prosternum shorter.

Length $6 \mathrm{~mm}$., width $1.3 \mathrm{~mm}$.

Type locality.-Talparo, Trinidad, British West Indies.

Type, allotype, and paratype.-U.S.N.M. No. 56604. Paratypes returned to Mr. Callan.

Remarks.-Described from five specimens, two males and three females (one male type), collected by E. McC. Callan. The type and allotype were collected at the type locality, December 25, 1941, and three paratypes were collected at Mundo Neuvo, Trinidad, April 4, 1943.

This species is allied to Agritus nigripennis Waterhouse but differs from that species in having the front of the head wider and convex and the pronotum without a deep depression in front of the scutellum and without prehumeral carinae.

AGRILUS TRINIDADENSIS, new species

Mate.-Elongate, rather slender, subcylindrical, feebly shining; head greenish black on front, becoming brownish black on occiput; pronotum and scutellum brownish black; elytra greenish black; underside of body black, with a faint bronzy-green reflection.

Head with front rather narrow, distinctly wider at top than at bottom, with a broad, longitudinal, median depression extending from occiput to clypeus; sides parallel along occiput and vertex, strongly, obliquely converging from vertex to bottom; surface densely granulose, coarsely, shallowly, and confluently punctate, clothed with a few short, semierect, inconspicuous, white hairs along sides and behind clypeus; clypeus narrow between antennae, deeply, arcuately emarginate in front. Antenna extending to apical third of pronotum, serrate from fourth segment.

Pronotum distinctly wider than long, wider at apex than at base, widest near apex; sides nearly parallel along apical half, then arcuately converging to near posterior angles, which are rectangular and slightly projecting outward; marginal and submarginal carinae slightly sinuate, widely separated anteriorly, the submarginal carina not connected with the marginal carina, and obsolete behind middle; anterior margin slightly sinuate, median lobe slightly produced and broadly rounded; base arcuately emarginate on each side, median lobe slightly produced, and broadly truncate in front of scutellum; disk rather deeply, broadly depressed in front of scutellum, very broadly, deeply depressed along 
lateral margins, vaguely flattened at middle along anterior margin; prehumeral carinae strongly elevated, sinuate, extending from base to basal third, not united to marginal carinae; surface glabrous, finely, densely granulose, finely, irregularly rugose on disk, finely, densely punctate between rugae. Scutellum strongly, transversely carinate.

Elytra broadly, arcuately constricted in front of middle; tips separately, broadly rounded and finely dentate; surface slightly flattened on basal half, finely, densely scabrous, sparsely, uniformly clothed with very short, recumbent, inconspicuous hairs.

Abdomen narrowly exposed above, strongly convex beneath; surface obsoletely granulose, with fine crenulate lines on basal sternites, sparsely clothed with short, recumbent, white hairs, with a longitudinal, median row of long, dense, white hairs on first and second sternites, and small patches of slightly denser, white hairs at sides of fourth and fifth sternites; suture between first and second sternites obsolete. Prosternum finely, densely granulose, densely clothed with moderately long, erect, white hairs; prosternal lobe long, broadly subtruncate in front; prosternal process broad, sides nearly parallel, apex obliquely converging to an obtuse, median tooth. Tarsal claws dissimilar on all feet; anterior and middle pairs cleft near tips, the teeth nearly equal in length and inner ones not turned inward; posterior pair cleft near middle, the inner tooth shorter than the outer one.

Female.-Unknown.

Length $7 \mathrm{~mm}$., width $1.6 \mathrm{~mm}$.

Type Tocality.-Talparo, Trinidad, British West Indies.

Type.-U.S.N.M. No. 56605.

Remarks.-Described from the single male type collected December 25, 1941, by E. McC. Callan.

This species is allied to Agritus latifrons Waterhouse but differs from that species in being of a different color, in having the front of the head narrower, with the sides strongly converging anteriorly, and not very deeply depressed at the middle, the surface of the pronotum more finely rugose, the elytra more strongly acuminate posteriorly and the surface more finely scabrous, and the abdominal sternites without distinct pubescent spots at the lateral margins. 


\section{$2 \mathrm{BHL}$ Biodiversity Heritage Library}

Fisher, Warren Samuel. 1943. "New species of buprestid beetles of the genus Agrilus from Trinidad." Proceedings of the United States National Museum 93(3167), 375-380. https://doi.org/10.5479/si.00963801.3167.375.

View This Item Online: https://www.biodiversitylibrary.org/item/31779

DOI: https://doi.org/10.5479/si.00963801.3167.375

Permalink: https://www.biodiversitylibrary.org/partpdf/20471

\section{Holding Institution}

Smithsonian Libraries

\section{Sponsored by}

Smithsonian

\section{Copyright \& Reuse}

Copyright Status: NOT_IN_COPYRIGHT

Rights: https://www.biodiversitylibrary.org/permissions/

This document was created from content at the Biodiversity Heritage Library, the world's largest open access digital library for biodiversity literature and archives. Visit BHL at https://www.biodiversitylibrary.org. 